\title{
Pengaruh Mengonsumsi Tomat Ceri (Solanum lycopersicum L. var. cerasiforme) Terhadap Indeks Gingiva
}

\author{
Carolina $B^{1}$, Soegiharto GS ${ }^{1}$, Evacuasiany $E^{1}$ \\ 1.Falkutas Kedokteran Gigi, Universitas Kristen Maranatha, 40164, Indonesia \\ Email: belincarolina@gmail.com
}

\begin{abstract}
Abstrak
Penyakit periodontal adalah suatu proses peradangan akibat interaksi antara serangan bakteri dan host respon inflamasi. Gingivitis adalah peradangan di dalam jaringan periodonsium yang terbatas pada gingiva. Senyawa yang dapat mengurangi inflamasi dapat ditemukan pada senyawa yang terkandung dalam buah tomat. Likopen adalah salah satu senyawa yang terkandung dalam buah tomat yang memiliki peran antioksidan dan memiliki efek anti-inflamasi. Penelitian ini bertujuan untuk mengetahui pengaruh sesudah mengonsumsi tomat ceri (Solanum lycopersicum L. var. cerasiforme) terhadap indeks gingiva.

Penelitian ini menggunakan metode eksperimental semu dengan desain pre dan post test terhadap indeks gingiva yang dilakukan dengan menggunakan metode Modified Gingival Index (MGI). Data yang diukur adalah selisih skor indeks gingiva sebelum dan sesudah mengonsumsi tomat. Subjek penelitian terdiri dari 26 orang. Penelitian dilakukan selama 7 hari dengan 3 kali pemeriksaan yaitu pada hari pertama, hari ke-3, dan hari ke-7. Analisis data indeks gingiva dilakukan dengan menggunakan Wilcoxon sign rank test dan Kruskal-Wallis test.

Hasil penelitian rerata indeks gingiva setelah mengonsumsi tomat ceri (Solanum lycopersicum L. var. cerasiforme) pada hari ke-1 sebesar 0.35, pada hari ke-3 sebesar 0.25 , dan pada hari ke-7 sebesar 0.12. Hasil analisis data didapatkan nilai $\mathrm{p}<0.05$ yang artinya terdapat perbedaan yang signifikan antara rata-rata indeks gingiva pada hari ke-1, hari ke-3, dan hari ke-7.

Simpulan penelitian ini adalah mengonsumsi tomat ceri (Solanum lycopersicum L. var. cerasiforme) dapat menurunkan indeks gingiva.
\end{abstract}

\section{The Effect of Consuming Cherry Tomatoes (Solanum lycopersicum L. var. cerasiforme) on The Gingival Index}

\begin{abstract}
Periodontal disease is an inflammatory process due to interactions between bacterial attacks and host inflammatory responses. Gingivitis in inflammation in the tissue of the periodontium which is confined to the gingiva. Compounds that can reduce inflammation can be found in compounds contained in tomatoes. Lycopene is one of the compounds contained in tomatoes which has the role of antioxidants and has anti-inflammatory effects. This study aims to determine the effect after consuming cherry tomatoes (Solanum lycopersicum L. var. cerasiforme) on the gingival index.

This study used a quasi-experimental method with the design of the pre and post test of the gingival index using the Modified Gingival Index (MGI) method. The data obtained were the difference in gingival index scores before and after consuming
\end{abstract}


tomatoes. The research subjects consisted of 26 people. The study was conducted for 7 days with 3 examinations, on the first day, day 3, and day 7. Data analysis of gingival index using Wilcoxon Sign rank test and Kruskal-Wallis test.

The result of the average in gingival index after consuming cherry tomatoes (Solanum lycopersicum L. var. cerasiforme) on day 1 is 0.35 , on day 3 is 0.25 , and on day 7 is 0.12 . the result of data anaylsis obtained a value $p<0.05$, which means that there are significant differences between the average gingival index on day 1, day 3, and day 7.

The conclusion of this study is consuming cherry tomatoes (Solanum lycopersicum L. var. cerasiforme) can decrease the gingival index.

Keywords: cherry tomatoes (Solanum lycopersicum L. var. cerasiforme); gingival index

\section{Pendahuluan}

Data dari Riset Kesehatan Dasar (RISKESDAS) tahun 2013 menunjukkan prevalensi nasional masalah gigi dan mulut sebesar 25,9\%. Karies dan penyakit periodontal merupakan dua penyakit gigi dan mulut yang merupakan masalah utama bagi kesehatan gigi dan mulut di Indonesia. Prevalensi penyakit periodontal pada semua kelompok umur di Indonesia yaitu 96,38\%. ${ }^{1}$ Berdasarkan data di atas, penanggulangan penyakit gigi dan mulut di masyarakat merupakan masalah prioritas bagi pemerintah khususnya dinas kesehatan, karena kesehatan gigi dan mulut pada dasarnya merupakan kesehatan tubuh secara keseluruhan. Salah satu penyakit gigi dan mulut yang memiliki prevalensi cukup tinggi di Indonesia adalah gingivitis. Di Indonesia, menurut data dari Riset Kesehatan Dasar (RISKESDAS) tahun 2013, prevalensi gingivitis menduduki urutan kedua terbanyak yaitu 96,58\%.2,3

Penyakit periodontal adalah penyakit yang kehilangan struktur kolagennya pada daerah penyangga gigi, sebagai respon dari akumulasi bakteri di jaringan periodontal. Penyakit periodontal merupakan penyakit infeksi yang menyerang gingiva dan jaringan pendukung gigi lainnya, jika tidak dilakukan perawatan yang tepat dapat mengakibatkan kehilangan gigi. ${ }^{4}$

Gingivitis adalah peradangan di dalam jaringan periodonsium yang terbatas pada gingiva, disebabkan oleh mikroorganisme yang membentuk suatu koloni serta membentuk plak gigi tetapi jika dibiarkan dapat berlanjut pada periodontitis. ${ }^{2}$ Gingivitis merupakan penyakit awal yang bersifat reversibel dan dapat dicegah dengan menyikat gigi setiap hari, flossing, serta pemeriksaan dan pembersihan (scalling) secara berkala oleh dokter gigi. Pada gingivitis tidak terdapat kehilangan jaringan keras atau tulang, dengan demikian penting untuk mengobati gingivitis sedini mungkin. ${ }^{5}$ Kondisi yang sangat umum dari gingivitis ditandai dengan terjadinya peradangan tanpa rasa sakit pada gingiva, adanya edema dan eritema disertai perdarahan pada tekanan ringan seperti saat menyikat gigi. 6

Senyawa yang dapat mengurangi inflamasi dapat ditemukan pada senyawa bioaktif yang terkandung dalam buah tomat. Buah tomat adalah salah satu buah yang paling dikenal oleh masyarakat dan memiliki keuntungan dalam memenuhi kebutuhan masyarakat seperti biaya, manfaat, ketersediaan, dan rasa. Secara 
kuantitatif, tomat adalah buah yang paling banyak dikonsumsi dan merupakan sumber likopen yang paling baik serta antioksidan kuat yang memiliki bioavailabilitas lebih tinggi setelah proses pemasakan dan pengolahan. Sejumlah besar penelitian menunjukkan manfaat mengonsumsi tomat dalam mencegah beberapa penyakit seperti kanker, penyakit kardiovaskular, osteoporosis, kerusakan kulit, dan disfungsi kognitif. $^{7}$

Buah tomat memiliki bentuk bervariasi, salah satunya adalah tomat ceri. Tomat ceri (Solanum lycopersicum L. var. cerasiforme) adalah jenis tomat yang populer terutama karena pengakuannya dari kualitas yang baik dan rasa yang baik. Tomat ceri memiliki warna merah terang dan rasa yang lebih manis dibandingkan dengan tomat jenis lainnya, juga memiliki kandungan antioksidan dan senyawa fitokimia yang tinggi, termasuk karotenoid, flavonoid, vitamin $\mathrm{C}$, dan banyak nutrisi penting lainnya. 8,9

Karotenoid adalah agen antioksidan yang kuat dan penting dalam pemeliharaan kesehatan seseorang secara menyeluruh dan memiliki peran protektif terhadap kanker, penyakit jantung, dan penyakit juga keganasan rongga mulut. Di antara karotenoid, likopen adalah antioksidan yang paling kuat. ${ }^{10}$

Likopen adalah salah satu antioksidan yang dikenal paling kuat dan menjadi karotenoid dominan dalam tomat, juga merupakan pigmen karotenoid yang pada dasarnya bertanggung jawab untuk warna merah matang pada tomat. ${ }^{11}$ Likopen berperan sebagai produk perantara penting dalam biosintesis beberapa karotenoid, termasuk $\beta$-karoten, dan bertanggung jawab dalam fotosintesis dan photo-protection. Seperti semua karotenoid, likopen merupakan hidrokarbon poliunsaturasi. ${ }^{12}$ Likopen dilaporkan memiliki efek anti-inflamasi. 13

Identifikasi masalah penelitian ini adalah apakah mengonsumsi tomat ceri (Solanum lycopersicum L. var. cerasiforme) mempengaruhi indeks gingiva.

Tujuan penelitian ini adalah untuk mengetahui pengaruh sesudah mengonsumsi tomat ceri (Solanum lycopersicum L. var. cerasiforme) terhadap indeks gingiva.

\section{Metode Penelitian}

Alat yang digunakan dalam penelitian ini: Masker; Handscoon; Alat dasar (kaca mulut, sonde, pinset, ekskavator); Burnisher 'O'; Baki steril; Slabber; Timer; Senter; Gelas kumur; Panci infusa; Thermometer; Kompor; dan Timbangan digital.

Bahan yang digunakan dalam penelitian ini: Buah tomat ceri (Solanum lycopersicum L. var. cerasiforme); Cotton roll; dan Air.

Populasi penelitian adalah mahasiswa dan mahasiswi di Program Studi S1 Fakultas Kedokteran Gigi Universitas Kristen Maranatha yang memenuhi kriteria inklusi: Mengalami gingivitis berdasarkan kriteria Modified Gingival Index (MGI); Bersedia menjadi subjek penelitian; Telah menandatangani informed consent; Kesehatan umum baik; Tidak memakai protesa gigi; dan Tidak megonsumsi obatobatan seperti antibiotik. Kriteria eksklusinya meliputi: Adanya penyakit atau kelainan rongga mulut, contoh: abses yang dapat terlihat seperti pembengkakan gingiva; dan Mempunyai penyakit sistemik, karena pada beberapa penyakit sistemik 
seperti anemia yang dapat menyebabkan kepucatan pada gingiva.

Metode yang digunakan merupakan penelitian eksperimental semu dengan desain one group pre test-post test dan cara penilaiannya dilakukan terhadap gingiva menggunakan metode pengukuran indeks gingiva. Data hasil penelitian dimasukkan ke dalam tabel, kemudian dianalisis dan diolah menggunakan perangkat jaringan lunak SPSS untuk melihat perbedaan pre-post menggunakan uji $\mathrm{T}$ berpasangan / Paired Sample T-Test.

\section{Hasil}

Penelitian ini merupakan penelitian eksperimental semu. Penelitian ini bertujuan untuk mengetahui pengaruh sesudah mengonsumsi tomat ceri (Solanum lycopersicum L. var. cerasiforme) terhadap indeks gingiva. Penelitian telah dilakukan kepada mahasiswa dan mahasiswi di Program Studi S1 Fakultas Kedokteran Gigi Universitas Kristen Maranatha dan didapatkan jumlah sampel sebanyak 26 orang. Indeks gingiva subjek penelitian dihitung terlebih dahulu menggunakan metode Modified Gingival Index (MGI) sebelum diberi perlakuan. Bahan yang diberikan adalah buah tomat ceri (Solanum lycopersicum L. var. cerasiforme) yang telah dimasak dengan teknik infusa sebanyak 16 gram atau setara dengan 4 buah tomat ceri (Solanum lycopersicum L. var. cerasiforme) berukuran sedang. Selama 7 hari berturut-turut subjek diberi 16 gram buah tomat ceri setiap harinya untuk dikonsumsi, kemudian dilakukan kembali pemeriksaan dengan mengukur indeks gingiva dengan metode Modified Gingival Index (MGI) pada hari ke-3 dan hari ke-7.

Penelitian pengaruh mengonsumsi tomat ceri (Solanum lycopersicum L. var. cerasiforme) terhadap indeks gingiva yang dilakukan selama 7 hari pada 26 subjek penelitian, maka didapatkan hasil:

\section{Distribusi Indeks Gingiva}

Gambaran umum karakteristik 26 subjek penelitian berdasarkan indeks gingiva, ditampilkan pada Tabel 1 berikut:

Tabel 1 Distribusi Indeks Gingiva

\begin{tabular}{llllll}
\hline Kelompok & $\mathrm{N}$ & $\begin{array}{l}\mathrm{Mi} \\
\mathrm{n}\end{array}$ & Max & $\begin{array}{l}\text { Rata- } \\
\text { rata }\end{array}$ & $\begin{array}{l}\text { St. } \\
\text { Dev }\end{array}$ \\
\hline Hari ke-1 & 26 & $\begin{array}{l}0,1 \\
3\end{array}$ & 0,96 & 0,35 & 0,19 \\
Hari ke-3 & 26 & $\begin{array}{l}0,0 \\
4\end{array}$ & 0,83 & 0,25 & 0,17 \\
Hari ke-7 & 26 & $\begin{array}{l}0,0 \\
0\end{array}$ & 0,50 & 0,12 & 0,12 \\
\hline
\end{tabular}




\section{Diagram 1 Grafik Rata-rata Indeks Gingiva}

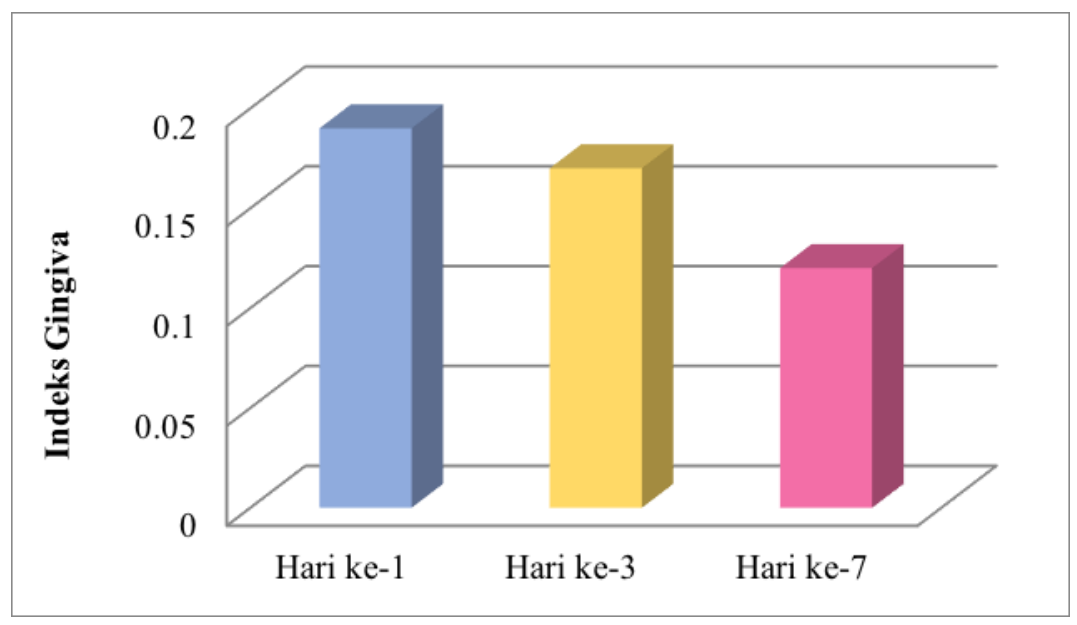

Berdasarkan Tabel 1, pada kelompok indeks gingiva hari ke-1 diketahui bahwa nilai minimum indeks gingiva sebasar 0,13 , nilai maximum sebesar 0,86 , dengan ratarata sebesar 0,35 dan standar deviasi sebesar 0,19. Pada kelompok indeks gingiva hari ke-3 didapatkan nilai minimum indeks gingiva sebesar 0,04 , nilai maximum sebesar 0,83 , dengan rata-rata sebesar 0,25 dan standar deviasi sebesar 0,17 dan pada kelompok indeks gingiva hari ke-7 didapatkan nilai minimum indeks gingiva sebasar 0,00 , nilai maximum sebesar 0,50 dengan rata-rata sebesar 0,12 dan standar deviasi sebesar 0,12 .

\section{$\underline{\text { Uji Normalitas }}$}

Sebelum dilakukan uji hipotesis maka terlebih dahulu dilakukan uji normalitas data. Jika data terdistribusi normal maka selanjutnya diuji menggunakan uji $t$ berpasangan sedangkan jika tidak berdistribusi nomal maka akan dilakukan uji Wilcoxon Sign rank test. Adapun pegujian normalitas digunakan uji Shapiro-Wilk untuk data $<50$ dengan kaidah yang digunakan adalah:

- Jika $a>0,05$ maka data terdistribusi normal

- Jika $a<0,05$ maka data terdistribusi tidak normal.

Hasil uji normalitas ditampilkan pada tabel di bawah ini:

Tabel 2 Normalitas Data

\begin{tabular}{llll}
\hline Indeks Plak Gigi & & $\begin{array}{l}\text { alpha } \\
(\alpha)\end{array}$ & $\begin{array}{l}\mathrm{p}- \\
\text { value }\end{array}$ \\
\hline $\begin{array}{l}\text { Sebelum mengonsumsi } \\
\text { (hari ke-1) }\end{array}$ & tomat ceri & 0,05 & 0,019 \\
$\begin{array}{l}\text { Sesudah mengonsumsi } \\
\text { (hari ke-3) }\end{array}$ & tomat ceri & 0,05 & 0,001 \\
$\begin{array}{l}\text { Sesudah mengonsumsi } \\
\text { (hari ke-7) }\end{array}$ & tomat ceri & 0,05 & 0,001 \\
\hline
\end{tabular}


Tabel 2 menunjukkan uji normalitas indeks gingiva sebelum dan sesudah mengonsumsi tomat ceri (Solanum lycopersicum L. var. cerasiforme). Berdasarkan hasil pengujian didapatkan nilai $\mathrm{p}$ untuk semua kelompok $<\alpha(0,05)$ sehingga dapat disimpulkan bahwa semua kelompok perlakuan tidak berdistribusi normal. Oleh karena itu, pengujian terhadap data dilakukan menggunakan metode Non parametrik Wilcoxon Sign rank test.

Perbandingan Indeks Gingiva Sebelum dan Sesudah Mengonsumsi Tomat Ceri (Solanum lycopersicum L. var. cerasiforme) Pada Hari ke-3

Hasil uji perbandingan indeks gingiva sebelum dan sesudah mengonsumsi tomat ceri (Solanum lycopersicum L. var. cerasiforme) hari ke-3 dapat dilihat pada tabel di bawah ini:

\section{Tabel 3 Perbandingan Indeks Gingiva Sebelum dan Sesudah Mengonsumsi Tomat Ceri Hari Ke-3}

\begin{tabular}{|c|c|c|c|}
\hline Kelompok & $\begin{array}{l}\text { Rata-rata } \\
\text { Indeks } \\
\text { Gingiva }\end{array}$ & alpha $(\alpha)$ & $\mathrm{p}$-value \\
\hline $\begin{array}{l}\text { Sebelum (Hari ke-1) } \\
\text { Sesudah (Hari ke-3) }\end{array}$ & $\begin{array}{l}0,35 \\
0,25\end{array}$ & $\begin{array}{l}0,0 \\
5\end{array}$ & 0,000 \\
\hline
\end{tabular}

Berdasarkan hasil uji Wilcoxon Sign rank test. indeks gingiva sebelum (hari ke-1) dan sesudah mengonsumsi tomat ceri (Solanum lycopersicum L. var. cerasiforme) hari ke-3, didapatkan nilai $\mathrm{p}(0,000)<\alpha(0,05)$. Artinya terdapat perbedaan yang signifikan antara indeks gingiva sebelum (hari ke-1) dan sesudah mengonsumsi tomat ceri (Solanum lycopersicum L. var. cerasiforme) hari ke-3.

Perbandingan Indeks Gingiva Sebelum dan Sesudah Mengonsumsi Tomat Ceri (Solanum lycopersicum L. var. cerasiforme) Pada Hari ke-7

Hasil Uji perbandingan indeks gingiva sebelum dan sesudah mengonsumsi tomat ceri (Solanum lycopersicum L. var. cerasiforme) hari ke-7 dapat dilihat pada tabel di bawah ini:

Tabel 4 Perbandingan Indeks Gingiva Sebelum dan Sesudah Mengonsumsi Tomat Ceri Hari Ke-7

\begin{tabular}{|c|c|c|c|c|}
\hline Kelompok & & $\begin{array}{c}\text { Rata-rata } \\
\text { Indeks Gingiva }\end{array}$ & alpha $(\alpha)$ & $\mathrm{p}$-value \\
\hline Sebelum (Hari ke-1) & 0,35 & & 0,05 & 0,000 \\
\hline
\end{tabular}


Berdasarkan hasil uji Wilcoxon Sign rank test. indeks gingiva sebelum (hari ke-1) dan sesudah mengonsumsi tomat ceri (Solanum lycopersicum L. var. cerasiforme) hari ke-7, didapatkan nilai $\mathrm{p}(0,000)<\alpha(0,05)$. Artinya terdapat perbedaan yang signifikan antara indeks gingiva sebelum (hari ke-1) dan sesudah mengonsumsi tomat ceri (Solanum lycopersicum L. var. cerasiforme) hari ke-7.

Perbandingan Indeks Gingiva Sesudah Mengonsumsi Tomat Ceri (Solanum lycopersicum L. var. cerasiforme) Pada Hari ke-3 dan Hari ke-7

Hasil Uji perbandingan indeks gingiva sesudah mengonsumsi tomat ceri (Solanum lycopersicum L. var. cerasiforme) hari ke-3 dan hari ke-7 dapat dilihat pada tabel di bawah ini:

Tabel 5 Perbandingan Indeks Gingiva Sesudah Mengonsumsi Tomat Ceri Pada Hari ke-3 dan Hari ke-7

\begin{tabular}{cclc}
\hline Kelompok & $\begin{array}{c}\text { Rata-rata } \\
\text { Indeks Gingiva }\end{array}$ & alpha $(\alpha)$ & p-value \\
\hline Hari ke-3 & 0,25 & 0,05 & 0,000 \\
Hari ke-7 & 0,17 & & \\
\hline
\end{tabular}

Berdasarkan hasil uji Wilcoxon Sign rank test. indeks gingiva sesudah mengonsumsi tomat ceri (Solanum lycopersicum L. var. cerasiforme) hari ke-3 dan hari ke-7, didapatkan nilai $\mathrm{p}(0,000)<\alpha(0,05)$. Artinya terdapat perbedaan yang signifikan antara indeks gingiva sesudah mengonsumsi tomat ceri (Solanum lycopersicum L. var. cerasiforme) pada hari ke-3 dan hari ke-7.

Penurunan Indeks Gingiva Sesudah Mengonsumsi Tomat Ceri (Solanum lycopersicum L. var. cerasiforme)

Tabel 6 Penurunan Indeks Gingiva Sesudah Mengonsumsi Tomat Ceri

\begin{tabular}{|c|c|c|c|c|}
\hline $\begin{array}{l}\text { Kelomp } \\
\text { ok }\end{array}$ & $\mathrm{n}$ & $\begin{array}{l}\text { Rata-rata } \\
\text { Penurunan } \\
\text { Indeks } \\
\text { Gingiva }\end{array}$ & $\begin{array}{l}\text { St. } \\
\text { De } \\
\text { v }\end{array}$ & $\begin{array}{c}\mathrm{p}- \\
\text { value }\end{array}$ \\
\hline $\begin{array}{l}\text { Penurunan Indeks Gingiva } \\
\text { (hari ke } 1 \text { - hari ke } 3 \text { ) }\end{array}$ & 26 & 0,106 & 0,075 & \\
\hline $\begin{array}{l}\text { Penurunan Indeks Gingiva } \\
\text { (hari ke } 1 \text { - hari ke } 7 \text { ) }\end{array}$ & 26 & 0,235 & 0,107 & 0,000 \\
\hline $\begin{array}{l}\text { Penurunan Indeks Gingiva } \\
\text { (hari ke } 3 \text { - hari ke } 7 \text { ) }\end{array}$ & 26 & 0,129 & 0,074 & \\
\hline
\end{tabular}


Berdasarkan hasil pengujian statistik dengan Uji Kruskal Wallis didapatkan nilai $\mathrm{p}$ $0,000<\alpha(5 \%)$ artinya terdapat perbedaan bermakna antara penurunan indeks gingiva pada masing- masing selisih kelompok perlakuan.

\section{Diskusi}

Indeks gingiva adalah pengukuran atau penilaian yang digunakan untuk mengevaluasi kasus gingivitis berdasarkan inspeksi visual gingiva yang mempertimbangkan warna dan ketegasan jaringan gingiva. Gingivitis merupakan

inflamasi di dalam jaringan periodonsium yang terbatas pada gingiva. 5,41

Susunan molekul yang memediasi respon inflamasi diantaranya adalah radikal bebas dan reactive oxygen species (ROS). Reactive oxygen species (ROS) dapat menyebabkan kerusakan jaringan dengan memulai reaksi rantai radikal bebas. Oleh karena itu, diperlukan antioksidan pelindung untuk menghilangkan oksidan berbahaya atau reactive oxygen species (ROS), juga untuk memperbaiki kerusakan yang disebabkan oleh reactive oxygen species (ROS). ${ }^{12}$

Pada buah tomat ditemukan senyawa fitokimia karotenoid yang merupakan agen antioksidan. Diantara karotenoid, likopen adalah fitokimia utama dalam buah tomat karena peran antioksidan yang kuat terkait dengan kemampuannya untuk bertindak sebagai pemulung radikal bebas. Akumulasi radikal bebas dalam tubuh akan menghasilkan suatu keadaan yang disebut sebagai stress oksidatif yang dihasilkan dari ketidakseimbangan reactive oxygen species (ROS) dalam sel. Reactive oxygen species (ROS) dapat ekspresi gen sitokin pro- dan anti- inflamasi. Telah ditunjukkan bahwa likopen akan menghambat aktivasi ini. Likopen akan menghambat sitokin proinflamasi seperti tumor necrosis factor-alpha (TNF- $\alpha$ ), interleukin-6 (IL-6), dan interleukin-8 (IL-8) yang akan meningkatkan respon inflamasi, serta merangsang produksi sitokin anti-inflamasi seperti interleukin-10 (IL-10) untuk mengendalikan inflamasi. Sementara antioksidan dalam likopen akan menjadi salah satu sistem pertahanan tubuh yang akan menetralisir radikal bebas yang ada. Antioksidan akan menetralisasi radikal bebas dalam tubuh dengan cara memberikan satu elektronnya sehingga terbentuk molekul yang stabil dan mengakhiri reaksi radikal bebas. ${ }^{14,36,39}$

Bioavailabilitas likopen dapat dipengaruhi oleh beberapa faktor, yaitu pecahnya matriks makanan, suhu pemasakan, kehadiran lipid, dosis, dan senyawa larut lainnya termasuk karotenoid lainnya. Beberapa penelitian telah menunjukan bahwa likopen dari tomat atau

produk tomat yang diproses secara termal memiliki bioavailabilitas lebih tinggi daripada likopen dari tomat segar, sehingga dapat meningkatkan efektivitas dari likopen. 11,14

Pada penelitian yang telah dilakukan, hasil dari penelitian memperlihatkan bahwa buah tomat ceri (Solanum lycopersicum L. var. cerasiforme) mengandung zat yang memiliki daya antioksidan dan anti-inflamasi yang dapat menurunkan indeks gingiva sehingga dapat mengurangi inflamasi gingiva. Penelitian ini dilakukan pada 26 subjek penelitian dimana diperoleh rerata indeks gingiva pada hari ke- 1 adalah 0,35 , pada hari ke-3 adalah 0,25 , dan pada hari ke-7 adalah 0,12. Adanya penurunan rerata indeks gingiva dapat disebabkan karena peran likopen yang merupakan senyawa fitokimia 
dalam buah tomat yang berperan sebagai antioksidan dan anti-inflamasi. ${ }^{14,24}$

Berdasarkan hasil uji statistik, terdapat perbedaan yang signifikan antara penurunan indeks gingiva pada masing-masing selisih kelompok perlakuan, dimana rerata penurunan indeks gingiva pada hari ke-1 sampai hari ke-3 adalah 0,106, pada hari ke-1 sampai hari ke-7 adalah 0,235, dan pada hari ke-3 sampai hari ke-7 adalah 0,129 . Penurunan rata-rata indeks gingiva terbesar adalah pada hari ke-1 sampai hari ke-7, hal ini dapat disebabkan karena konsumsi yang cukup besar dan berlangsung terus menerus hingga menjadi suatu kebiasaan dapat memenuhi berbagai nutrisi serta fitokimia yang diperlukan untuk melindungi tubuh dari kerusakan oksidatif. 42,43,44

Pada hasil penelitian yang telah dilakukan, terdapat variasi penurunan indeks gingiva pada subjek penelitian. Variasi penurunan indeks gingiva pada subjek penelitian dapat disebabkan oleh beberapa faktor, yaitu kondisi mulut dan kebiasaan yang berbeda pada setiap individu, serta makanan yang dikonsumsi.

Hasil uji statistik pada Tabel 4.6 menunjukkan bahwa nilai p $(0,000)$, artinya terdapat perbedaan yang signifikan ( $p$-value $<\alpha$ 5\%) dan $\mathrm{H}_{0}$ ditolak. Dengan demikian $\mathrm{H}_{1}$ diterima, yaitu terdapat perbedaan indeks gingiva sebelum dan sesudah mengonsumsi tomat ceri (Solanum lycopersicum L. var. cerasiforme). Maka disimpulkan bahwa mengonsumsi tomat ceri (Solanum lycopersicum L. var. cerasiforme) menurunkan indeks gingiva.

Adapun kekurangan dalam penelitian ini, dimana buah tomat ceri memiliki berbagai kandungan senyawa bioaktif yang memiliki banyak manfaat, salah satunya adalah mengurangi plak gigi. Plak gigi merupakan salah satu penyebab utama terjadinya gingivitis, sehingga jika plak gigi dihilangkan maka akan mengurangi gingivitis dimana indeks gingiva pun akan menurun. Oleh karena itu, pada penelitian yang telah dilakukan peneliti tidak dapat membedakan apakah penurunan indeks gingiva adalah hasil dari mekanisme kerja senyawa bioaktif likopen terhadap inflamasi gingiva atau pengaruh senyawa bioaktif lainnya dalam buah

tomat ceri yang mengurangi plak gigi sehingga menyebabkan penurunan indeks gingiva. Maka dari itu, dibutuhkan penelitian lebih lanjut untuk mengetahui pengaruh senyawa bioaktif likopen terhadap penurunan indeks gingiva.

\section{Kesimpulan}

Berdasarkan hasil penelitian dapat disimpulkan bahwa mengonsumsi tomat ceri (Solanum lycopersicum L. var. cerasiforme) dapat menurunkan indeks gingiva.

\section{Referensi}

1. Lestari DP, Wowor VNS, Tambunan E. Hubungan tingkat pengetahuan kesehatan gigi dan mulut dengan dtatus kesehatan jaringan periodontal pada penyandang diabetes melitus tipe 2 di RSUD manembo-nembo bitung. Jurnal e-gigi; 2016: 2(4): $188-195$

2. Nur RM, Krimariono A, Rubianto M. Gingivitis severity of patients at dental clinic puskemas sawahan surabaya in 2016 using gingivial index. Departemen 
Periodonsia Fakultas Kedokteran Gigi Universitas Airlangga SurabayaIndonesia; 2016.

3. Laksmiarti T, Rachmawati T, Angkasawati TJ. Pokok-pokok hasil riset kesehatan dasar, riskesdas 2013. Badan Penelitian dan Pengembangan Kesehatan, Kementrian Kesehatan; 2013.

4. Lumentut RAN, Gunawan PN, Mintjelungan CN. Status periodontal dan kebutuhan perawatan pada usia lanjut. Jurnal e-gigi; 2013: 2(1): 79-83

5. The American Academy of Periodontology. Treatment of plaque-induceced gingivitis, chronic periodontitis, and other clinical conditions. J Periodontol; 2001: 72: 1790-1800.

6. Bamadi M. Gingivitis and the environmental health: an overvire. Middle-East Journal of Scientific Research; 2013: 18(3): 283-287.

7. Freeman BB, Reimers L. Tomato consumption and health: emerging benefits. American Journal of Lifestyle Medicine; 2010: 10(10).

8. Menezes JBC, Costa CA, Sampaio RA, Catao HCRM, Guilherme DO, Martinez RAS. Fruit production and classification of four cherry tomato genotypes under an organic cropping system. IDESIA (Chile); 2012: 3(30): 29-35.

9. Razzak HA, Ibrahim A, Allah MW, Alsadon A. Response of cherry tomato (Solanum lycopersicum var. cersiforme) to pruning systems and irrigation rates under greenhouse conditions. Journal of Crop Science; 2013: 5: 275-285.

10. Dahan K, Fennal M, Kumar NB. Lycopene in the prevention of prostate cancer. J Soc Integr Oncol; 2008: 6: 29-36.

11. Marques CS, Lima R, Oliveira J, Lemos ET. Tomato lycopene: functional proprieties and health benefits.

12. Bhardwaj R, Chaudhary K, Kaur S, Gupta R, Kamal R, Kumar M. Lycopene in oral health. Indian J Oral Sci; 2013: 4: 125-129.

13. Lumentut RAN, Gunawan PN, Mintjelungan CN. Status periodontal dan kebutuhan perawatan pada usia lanjut. Jurnal e-gigi; 2013: 2(1): 79-83.

14. Raiola A, Rigano MM, Calafiore R, Frusciante L, Varone A. Enchancing the health- promoting effects of tomato fruit of biofortified food. Editors: Laura Di Renzo. Italy: Hindiawi. 2014 P. 1-16.

15. Carranza F.A., Newman M.G., Takei H.H., Klokkevold P.R. Carranza's Clinical Periodontology $12^{\text {th }}$ ed. Philadelphia: Saunders Elsevier; 2015.

16. Carranza F.A., Newman M.G., Takei H.H., Klokkevold P.R. Carranza’s Clinical 
Periodontology $9^{\text {th }}$ ed. Philadelphia: Saunders Elsevier; 2002; 16-18.

17. Bathla S. Periodontics Revisited. India: Jaypee Borthers Medical Pub.; 2011.

18. Yamamoto SL. Periodontal disease, symptoms, treatment and prevention. New York: Nova Biomedical; 2011

21. Carranza F.A., Newman M.G., Takei H.H., Klokkevold P.R. Carranza's Clinical Periodontology $9^{\text {th }}$ ed. Philadelphia: Saunders Elsevier; 2002; 29-31.

22. Carranza F.A., Newman M.G., Takei H.H., Klokkevold P.R. Carranza's Clinical Periodontology $9^{\text {th }}$ ed. Philadelphia: Saunders Elsevier; 2002; 80.

23. Adams KC, Campbell JK, Zaripheh S, Jeffery EH, Erdman JW. The tomato as a functional food. The Journal of Nutrition. 2005;5(135);1226-1230.

24. Eveline, Siregar TM, Sanny. Studi aktivitas antioksidan pada tomat konvensional dan organik selama penyimpanan. 2014: 1(1): 22-28

25. Pracaya. Bertanam Tomat. Yogyakarta: Kaninus, 1998.

26. Maong R, Rorong JA, Fatimah F. Aktivitas ekstrak buah tomat sebagai penstabil oksigen singlet dalam reaksi fotooksidasi asam linoleat. Jurnal MIPA Unstrat; 2016: 1(5): 60-64

27. Kailaki SI, Deandari KT, Sunarmani. Potensi likopen dalam tomat untuk kesehatan. 2017: 1(3): 50-58

36. Vincent RR, Appukuttan D, Prakash PSG, Victor DH. Oxidative stress: role in pathogenesis of periodontal disease. International Journal of Pharma and Bio Science; 2017: 8(3).

37. Tothova L, Celec P. Oxidatve stress and antioxidants in the diagnosis and therapy of periodontitis. Front. Physiol; 2017: 8.

38. Pendyala G, Thomas B, Kumari S. The challenge of antioxidants to free radicals in periodontitis. Journal of Indian Society of Periodontology; 12(3); 78-83.

39. Kaur G, Kathariya R, Bansal S, Singh A, Shahakar D. Dietary antioxidants and their indespensable role in periodontal health. Journal of Food and Drug Analysis; 2016: 24: 239-246

41. Mosby's Dental Dictionary. $2^{\text {nd }}$ ed. Mosby Elsevier; 2008.

42. Kailaki SI, Dewandari KT, Sunarmani. Potensi likopen dalam tomat untuk kesehatan. Balai Besar Penelitian dan Pengembangan Pascapanen Pertanian. 2007;3:50-58. 
43. Campbell JK, Adams KC, Lindshield BL, Boileau TWM, Clinton SK, Erdman JW. Tomato phytochemicals and prostate cancer risk. The Journal of Nutrition. 2007; 134.

44. Etminan M, Takkouche B, Caamano-Isorna F. The role of tomato products and lycopene in prevention of prostate cancer: a meta-analysis of observational studies. AACR Contennial Conference. 2004; 13: 340-345. 